\title{
НЕКОТОРЫЕ АСПЕКТЫ БОРЬБЫ С ОТДЕЛЬНЫМИ ПРЕСТУПЛЕНИЯМИ В СФЕРЕ НАЛОГООБЛОЖЕНИЯ
}

\section{SOME ASPECTS OF THE FIGHT AGAINST CERTAIN CRIMES IN THE FIELD OF TAXATION}

\section{Filimonov \\ I. Gunkin \\ D. Rubtsov}

Summary: The article is devoted to the problems of combating crimes in the field of taxation. The authors proposed a methodology for identifying, documenting and disclosing certain types of crimes associated with violation of Russian legislation on taxes and fees.

Keywords: police, tax, tax crime, tax audit, operational-search activity.
$\mathrm{H}$ алоговые преступления относятся к числу наиболее общественно опасных деяний, причиняющих материальный ущерб государству. Обеспечение экономической безопасности в налоговой сфере является одним из приоритетных направлений деятельности органов внутренних дел.

Анализ следственно-судебной практики показывает, что количество выявленных налоговых преступлений ежегодно снижается. Так, если за 2016 год сотрудниками органов внутренних дел было выявлено 8106 налоговых преступлений, то в 2017 году - 7657 налоговых преступлений (снижение на 5,5\%), в 2018 году - 6757 налоговых преступлений (снижение на 11,8\%), а в 2019 году - всего 4157 налоговых преступления [1].

Причинами снижения выявленных преступлений рассматриваемой категории являются не только изменения уголовного законодательства, но и ряд иных обстоятельств, носящих как объективный, так и субъективный характер. В первую очередь необходимо отметить, что законодатель последовательно идёт по пути декриминализации рассматриваемого преступного деяния. Это выразилось в том, что минимальная сумма налогов и сборов, при уклонении от уплаты которой деяние считается преступным, была увеличена. Кроме того, законодатель включил в общую сумму налогов и сборов ещё и страховые взносы, которые при определении доли неуплаченных налогов должны рассчитываться с налогами и сборами в совокупности, тем самым ещё улучшив по-
Филимонов Иван Анатольевич

К.ю.н., дочент, Владивостокский филиал ФГКОУ ВО «ДВЮИ МВД России»

178303@mail.ru

Гунькин Игорь Валентинович

К.ф.н., дочент, Владивостокский филиал ФГКОУ ВО «ДВЮИ МВД России»

andrei_84-05@mail.ru

Рубцов Дмитрий Иванович

старший преподаватель, Владимирский юридический институт ФСИН России

dm.rubtsov@mail.ru

Аннотация: Статья посвящена проблематике борьбы преступлениями в сфере налогообложения. Авторами предложена методика выявления, документирования и раскрытия отдельных видов преступлений, связанных с нарушением законодательства России о налогах и сборах.

Ключевые слова: полиция, налог, налоговое преступление, налоговая проверка, оперативно-разыскная деятельность.

ложение налогоплательщика.

Также необходимо констатировать существенное сокращение сил и средств оперативных подразделений в сфере противодействия налоговым преступлениям при одновременном увеличении объёма оперативной информации, подлежащей проверке. Следует отметить и недостаточное количество следователей, специализирующихся на расследовании налоговых преступлений.

В этой связи представляется чрезвычайно важным качественное документирование налоговых преступлений, эффективное взаимодействие с лицами, обладающими специальными экономическими знаниями, разработка и внедрение методических рекомендаций по организации и проведению исследования документов по материалам проверки.

В Уголовном кодексе Российской Федерации (далее по тексту - УК РФ) предусмотрено 4 состава преступлений в сфере налогообложения, в связи с этим для каждого отдельного правонарушения есть собственная тактика раскрытия и документирования налоговых преступлений. Но так как общее число преступлений в сфере налогообложения не велико, и чаще всего нарушаются не все статьи, предусмотренные УК РФ в этой области, то будет целесообразным рассмотреть алгоритмы действий сотрудников только в некоторых самых распространенных преступлениях. 
Самый распространенный вид преступлений в сфере налогообложения это преступление, предусмотренное статьей 198 УК РФ «Уклонение от уплаты налогов и (или) сборов с физического лица» [2].

Во взаимодействии с налоговым органом в рамках участия в выездной либо камеральной налоговой проверке (на основании ст. 36 Налогового Кодекса РФ по запросу налоговых органов органы внутренних дел участвуют в совместных налоговых проверках, порядок взаимодействия органов внутренних дел и налоговых органов при организации и проведении выездных налоговых проверок утвержден Приказом МВД России и ФНС России № 495/ММ-7-2-347 от 30.06.2009 г.) [3], [4]. При данном варианте сотрудник подразделения экономической безопасности и противодействия коррупции (далее по тексту - ЭБиПК) является участником налоговой проверки физического лица либо индивидуального предпринимателя, осуществляя свою деятельность по документированию возможного правонарушения, как в рамках Налогового Кодекса РФ, так и в соответствии с Федеральным законом «О полиции», Федеральным законом «Об оперативно-розыскной деятельности», что дает возможность одновременно работать в рамках оперативноразыскного производства, осуществляя комплекс необходимых оперативно-розыскных мероприятий [5], [6].

В дальнейшем по итогам совместной налоговой проверки составляется акт, в течение двух месяцев выносится решение налогового органа о доначислении сумм налогов к уплате в бюджет, выносится требование об уплате налогов, при неуплате гражданином доначисленного налога через 2 месяца налоговый орган в соответствии с Соглашением о взаимодействии между СК РФ и ФНС РФ от 13.02.2012 г. № 101-162-12/MMB-27-2/3 и Протоколом № 1 к данному Соглашению направляет заявление в подразделение Следственного Комитета РФ для решения вопроса о возбуждении уголовного дела по ст. 198 УК РФ, а сотрудники подразделения ЭБиПК направляют результаты, полученные в ходе осуществления ОРД, в части документирования умысла физического лица на совершение данного преступления [7].

Документирование неуплаты налогов физическим лицом силами оперативных сотрудников ЭБиПК с привлечением специалистов-ревизоров отделения документальных исследований.

В данном варианте проверка проводится в рамках Федерального закона «О полиции» и Федерального закона «Об оперативно-розыскной деятельности». При сборе всех необходимых документов, подтверждающих факт неуплаты налогов физическим лицом, в том числе данных налогового органа о предоставлении налоговых деклараций, а также о суммах налогов, подлежащих уплате физическим лицом за три финансовых года, вклю- чая период неуплаты налогов, для расчета процентной доли неуплаченных налогов в соответствии с требованиями ст. 198 УК РФ, материалы предоставляются на проведение документального исследования в отделение документальных исследований ЭБиПК МВД России по субъекту Российской Федерации.

После получения заключения исследования ревизоров собранные материалы проверки и результаты ОРД направляются в СУ Следственного Комитета России для решения вопроса о возбуждении уголовного дела по ст. 198 УК РФ.

Еще одним часто совершаемым преступлением в сфере налогообложения является состав преступления, предусмотренный ст. 199.2 УК РФ «Сокрытие денежных средств либо имущества организации или индивидуального предпринимателя, за счет которых должно производиться взыскание налогов и (или) сборов».

Для раскрытия данного состава преступления сотруднику необходимо совершать все действия по пунктам, не допуская отклонений от намеченного алгоритма действий. Первоначальным этапом считается получение из налогового органа списков налогоплательщиков - юридических лиц и индивидуальных предпринимателей, задолженность которых перед бюджетом по налогам (без учета пеней и штрафов) превышает 2250000 руб. по состоянию на сегодняшний день, либо превышала указанную сумму, но в настоящий момент погашена (с учетом норм ч. 2 ст. 76.1 УК РФ, документирование преступления по ст. 199.2 УК РФ возможно и в случае наличия у налогоплательщика в предшествующий период недоимки по налогам в сумме, превышающей 2.25 млн. руб., и в настоящий момент погашенной, так как для освобождения от привлечения к уголовной ответственности необходимо погашение причиненного государству ущерба в двукратном размере).

Исключение из данного списка предприятий и ИП, находящихся в настоящее время в стадии банкротства (документирование признаков ст. 199.2 для предприятий в стадии банкротства возможно только по недоимке по текущим платежам, которые предприятие не уплатило уже после введения процедуры банкротства).

В случае образования недоимки по налогам за счет сумм, доначисленных по итогам камеральных и выездных налоговых проверок, необходимо установить, оспаривает ли налогоплательщик указанные доначисления в УФНС России, либо в арбитраже (в случае оспаривания проверочные мероприятия проводить нецелесообразно до вынесения судом решения).

Далее необходимо провести сверку с налоговым органом по оставшимся в списке предприятиям и ИП 
на предмет установления тех недоимщиков, к которым ИФНС применила все меры принудительного взыскания в соответствии с Налоговым Кодексом РФ (требования об уплате налогов, решения о взыскании налогов за счет денежных средств на счетах налогоплательщика в банках, инкассовые поручения на списание в принудительном порядке в соответствующие бюджеты денежных средств с расчетных счетов налогоплательщика), то есть у налогоплательщика на сумму недоимки по налогам, превышающей 2.25 млн. руб., должно быть выставлено требование налогового органа, вынесены решения о взыскании налогов за счет денежных средств на счетах в банках, на один расчетный счет должны быть выставлены инкассовые распоряжения на суммы налогов, указанные в требовании, а остальные расчетные счета должны быть перекрыты решениями налогового органа о приостановлении операций по счетам. Все данные сведения имеются в налоговом органе, необходимы копии всех требований, инкассовых распоряжений, решений о взыскании налогов за счет денежных средств на счетах в банках и решений о приостановлении операций по счетам, а также балансы расчетов на дату начала образования недоимки в 2.25 млн. руб., на дату вынесения требования об уплате налогов и на дату осуществления проверочных мероприятий (текущую дату).

Основной этап - это проведение проверочных мероприятий по предприятиям и ИП, к которым налоговым органом приняты все меры по взысканию недоимки, для выявления фактов сокрытия денежных средств и имущества от взыскания.

Необходимо отметить, что местом совершения преступления по ст. 199.2 УК РФ является место проведения расчетов денежными и иными средствами с целью сокрытия их от взыскания недоимки, то есть офис предприятия либо его контрагента, где производились расчеты, составлялись договора уступки либо письма-распоряжения и т.д. Соответственно, преступления данной категории могут быть задокументированы и направлены в подразделение СУ СК России по субъекту Российской Федерации в любом территориальном подразделении МВД России, а не только в тех, на территории оперативного обслуживания которых расположен налоговый орган.

Для того, чтобы предыдущие действия дали результат, при раскрытии преступления сотруднику необходимо знать и помнить возможные варианты сокрытия денежных средств, то есть расходов на цели, не связанные с уплатой налогов и сборов и с выплатой заработной платы, алиментов, по исполнительным листам по решению суда, которые могут применять правонарушители, а именно:

1. проведение расчетов с контрагентами через кассу предприятия, без взноса денежных средств (выручки) на расчетный счет;
2. открытие новых расчетных счетов и направление писем контрагентам для перечисления денежных средств на вновь открытые счета, не перекрытые инкассовыми распоряжениями налогового органа;

3. расчеты «через третьих лиц», то есть проведение взаимозачетов между дебиторами и кредиторами предприятия, без перечисления денежных средств напрямую на счет недоимщика;

4. договора цессии, то есть уступка права требования дебиторской задолженности, за данное переуступленное право требования расчеты производятся, также минуя перекрытые налоговым органом расчетные счета - либо на вновь открытый расчетный счет, либо зачетом взаимных требований.

Данные факты могут быть выявлены проведением встречных проверок у контрагентов предприятия, на самом предприятии (проведением осмотра места происшествия в рамках КУСП, обследования помещений в рамках ДОУ). Указанные взаиморасчеты отражаются в регистрах бухгалтерского учета предприятия по счетам $50,51,60,62,71,76$.

После получения документов о проведенных налогоплательщиком расчетах в обход перекрытых расчетных счетов необходимо направить имеющиеся материалы проверки на исследование в отделение документальных исследований ЭБиПК МВД России со следующей примерной формулировкой вопросов для исследования:

1. какова сумма недоимки?

2. какие меры приняты налоговым органом для взыскания недоимки?

3. какие расчеты осуществлял налогоплательщик с дебиторами и кредиторами в период перекрытия расчетных счетов налоговым органом?

Исследованием должно быть подтверждено то, что налогоплательщик в период наличия недоимки по налогам в сумме свыше 2.25 млн руб. и при перекрытых налоговым органом расчетных счетах осуществлял расчеты - расходовал денежные средства напрямую или через третьих лиц на цели, не связанные с уплатой налогов и сборов и с выплатой заработной платы, алиментов, по исполнительным листам по решению суда.

После получения заключения исследования ревизоров собранные материалы проверки и результаты ОРД необходимо направить в СУ Следственного Комитета России для решения вопроса о возбуждении уголовного дела по ст. 199.2 УК РФ.

В заключении считаем необходимым отметить, что к превентивным мерам помимо ужесточения санкций, вплоть до усиления уголовного преследования, можно 
отнести пропагандистское информирование, а именно:

1. формирование правовой культуры населения в вопросах налогового законодательства;

2. обеспечение широкого информирования общественности о результатах деятельности отделов по борьбе с экономическими и налоговыми пре- ступлениями;

3. создание среди широких слоев населения максимально благоприятного имиджа отделов по борьбе с экономическими и налоговыми преступлениями как быстро развивающейся, перспективной и необходимой правоохранительной структуры.

\section{ЛИТЕРАТУРА}

1. Сайт ЦСИ ФКУ «ГИАЦ МВД России» [Электронный ресурс]. URL: http://10.5.0.16 (дата обращения 07.10.2020). Доступ по паролю.

2. Уголовный кодекс Российской Федерации от 13.06.1996 № 63-Ф3 (ред. от 31.07.2020) // СПС КонсультантПлюс.

3. Налоговый кодекс Российской Федерации (часть первая) от 31.07.1998 № 146-Ф3 (ред. от 20.07.2020) (с изм. и доп., вступ. в силу с 01.10.2020) // СПС КонсультантПлюс.

4. Приказ МВД России № 495, ФНС России № ММ-7-2-347 от 30.06.2009 (ред. от 12.11.2013) «06 утверждении порядка взаимодействия органов внутренних дел и налоговых органов по предупреждению, выявлению и пресечению налоговых правонарушений и преступлений» (вместе с «Инструкцией о порядке взаимодействия органов внутренних дел и налоговых органов при организации и проведении выездных налоговых проверок», «Инструкцией о порядке направления органами внутренних дел материалов в налоговые органы при выявлении обстоятельств, требующих совершения действий, отнесенных к полномочиям налоговых органов, для принятия по ним решения», «Инструкцией о порядке направления материалов налоговыми органами в органы внутренних дел при выявлении обстоятельств, позволяющих предполагать совершение нарушения законодательства о налогах и сборах, содержащего признаки преступления») (Зарегистрировано в Минюсте России 01.09.2009 № 14675) // СПС КонсультантПлюс.

5. Федеральный закон от 07.02.2011 № 3-Ф3 (ред. от 06.02.2020) «0 полиции» // СПС КонсультантПлюс.

6. Федеральный закон от 12.08.1995 № 144-Ф3 (ред. от 02.08.2019) «0б оперативно-розыскной деятельности» // СПС КонсультантПлюс.

7. Дополнительное соглашение к Соглашению о взаимодействии между Следственным комитетом Российской Федерации и Федеральной налоговой службой от 13.02.2012 № 101-162-12/ММВ-27-2/3 (утв. СК России № 2262-18, ФНС России ММВ-23-11/25@ 24.12.2018) // СПС КонсультантПлюс.

\footnotetext{
( Филимонов Иван Анатольевич (178303@mail.ru ), Гунькин Игорь Валентинович (andrei_84-05@mail.ru ),

Рубцов Дмитрий Иванович (dm.rubtsov@mail.ru).

Журнал «Современная наука: актуальные проблемы теории и практики»
}

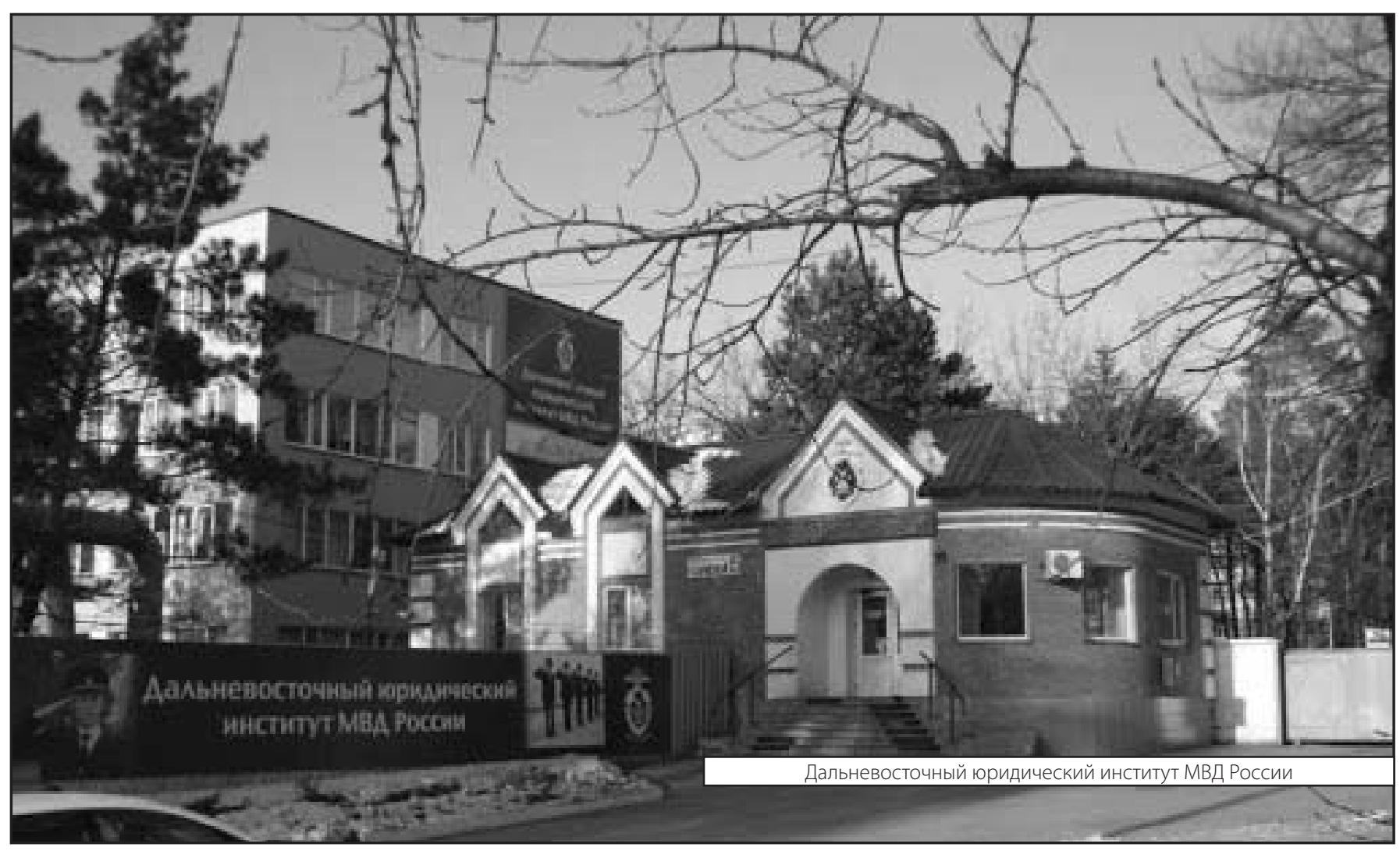

